\title{
Source Credibility: A Philosophical Analysis
}

\author{
Bonachristus Umeogu \\ Department of Philosophy, Faculty of Arts, Nnamdi Azikiwe University, Awka, Nigeria \\ Email: ojiakor99@yahoo.com \\ Received February 14 ${ }^{\text {th }}$ 2012; revised March $16^{\text {th }}, 2012$; accepted March $29^{\text {th }}, 2012$
}

\begin{abstract}
It is one thing to catch someone's attention and another thing to hold it for as long as the speaker desires. There must be something about those leaders and speakers who have been able to achieve this feat. The secret is source credibility which arises from how the public view or perceive a speaker. This research paper explaines the role of this important virtue in relation to advertisements, politics and religions. This paper is timely and significant because the most difficult form of management is human and mind management. The key is to be seen as a credible source. How is that possible?
\end{abstract}

Keywords: Ethos; Politics; Religion; Celebrity Advertising

\section{Introduction}

Have you bothered to question why people prefer one speaker to another? Have you witnessed a situation where worshippers lose interest in the day's service because a certain desired speaker is not the officiating priest? Have you ever experienced listening to a speaker on television and would not want to change the channel even when what he/she is saying makes little or no sense to you? The reason for the above scenario is source credibility and trustworthiness.

The Greek philosopher Aristotle understood this virtue and contextualized it by calling it ethos. Credibility and trustworthiness is a virtue that should be sought after by all and sundry regardless of age. These two virtues go hand in hand because there cannot be a basis of trust when one is not seen as credible. Without this quality, how can one make and keep friends? How can there be a relationship between man and wife? How can there be a religious organization when the members do not see the leader(s) as credible? How? How? How? It is now obvious that credibility transcend all facets of life cutting across religion, politics, family, advertising and what have you.

This paper having understood the logic of source credibility seeks to explain the concept of source credibility vis-à-vis politics, advertising and religion. What roles do being seen as a credible source play in the above mentioned areas? How far were they able to effectively pull off their roles? All these were explored in this paper.

\section{Explication of Terms}

By way of definition, source credibility can be seen as a situation where message believability is dependent on the credibility status of the sender in the minds and eyes of the receivers. Academic studies of the topic is said to have begun in the twentieth century and were given a special emphasis during the World War II when the Unites States government thought to use propaganda and mind management to influence public opinions in support of war efforts. The United States government employed early theoretical models of source credibility in creating the Committee on Public Information (CPI). It was an ambitious attempt to mould public opinions on an unprecedented scale.

Basically, CPI was primarily concerned with formulating principles that will aid effective communication so as to have the desired effect on the receivers. It also encouraged targeted publics to participate in the war effort through a variety of government programs, making them stakeholders in their government and increasing their sense of community. (Pinkerton, 1994 in Cornan et al., 2006)

In the course of this research, it was learnt that source credibility theory sprung out from the war department as a result of researches by Hovland and others, to test the communication processes that messages pass through from the source to the receiver. This source-message-receiver model is all that communication is about.

\section{Aristotelian Theory on Source Credibility}

The concept of source credibility was developed by Aristotle in a text of his works, called The Rhetoric. From the book, it became evident that Aristotle divided the means of persuasion into three categories: ethos, logos and pathos.

According to Aristotle, the rhetorician ethos plays the most important role in influencing the audiences thought and beliefs. It is what makes the speaker in the first place. Such an ethos implies the communicators' knowledge and understanding of the message coupled with moral authority and expressed goodwill of the message sender. This is where understanding and perceived expertise comes into play. It is the known contributing factor for the credibility and trust vested in the communicator. Baudhin and Davis (1972), and McCroskey (1958) concurred also affirms that the communicator's ethos plays an essential role in effectively persuading message receivers.

\section{Source Credibility Theory}

The source credibility theory as propounded by Hovland, Janis and Kelly (1963) stated that people or receivers are more likely to be persuaded when the source presents itself as credible. Furthermore, Hovland (1963) and Weiss (1974) later studied the influence of sources in persuasion. The study was done by comparing credible and non-credible sources using same 
persuasive message to test if the sources seen as credible could influence opinions change in the message receivers more than the non-credible source. The study confirmed the assumption that credible sources tend to create the desired impact on the audience.

On a similar note, McCroskey et al. (1974), submitted that communicators with high credibility in the eyes of message receivers tend to have respect and their words are accepted more readily. Also, middle Brook's findings (1974) showed that differences in receivers attitudes have a bearing to source credibility. There is obvious uniformity in communication theories that message receivers relate source credibility to the communicator's favorable character or ethos that emits knowledge, moral standards and goodwill towards the message receivers. That is, favorable senders' ethos equals credibility and believability.

Be that as it may, there are two most commonly visible elements which positively influence source credibility and they are: perceived expertise and trustworthiness of the source. Commenting on this is Cornan et al. (2006), who submitted that

...three key dimensions of credibility: trustworthiness, competence, and goodwill. These three dimensions are not empirical realities but perceptions that can be created, managed, and cultivated. This requires a coordinated approach to message design, delivery, and-most importantly-adaptation to the given audience and current media situation.

This will now be explored in advertising, politics and religions.

\section{Source Credibility and Advertising}

Have you bothered to question why companies spend huge amount of money to sign endorsement deals with models and celebrities all in the name of advertising purposes? The reason is that these models, stars and celebrities have assumed a role model status in the eyes of the consumers who on a daily basis aspire to be like them. If they reveal the name of a particular scent that they prefer to feel "sexy", then that revelation alone is enough to become the hand of Midas that will turn that particular product into gold. That should explain the relationship between source credibility and the product attractiveness which mostly translates into higher sales.

How do we see credibility in the world of advertising? As have been stated earlier in the course of this paper,

Credibility refers to a person's perception of the truth of a piece of information. It is a multi-dimensional concept that serves as a means for the receiver of the information to rate the source or transmitter of the communication in relation to the information. This rating correlates with the willingness of the receiver to attribute truth and substance to the information (Hovland et al., 1953 in Eisend, 2006).

Credibility is all about the tendency to believe or trust someone with little or no doubt of being deceived or manipulated. Faith, trust, love and objectivity are all rolled up in one word-credibility.

Before exploring further, who are celebrities? Schlecht (2003) defines "celebrities as people who enjoy public recognition by a large share of a certain group of people". I want to add that they are people who have excelled in their chosen careers and consequently have gained public awareness, recognition and approval. They include actors/actresses like Olu Jacobs, Brad
Pitt, Tom Cruise, Genevieve Nnaji; artistes like Tu face, D’Banj, P-Square, Celine Dion, Eminem, Beyonce Knowles; comedians in the person of Basket mouth; talkshow hosts like Oprah, Dr Phil; sports athletes like Jay Okocha, Kanu Nwankwo, Michael Jordan, Venus and Serena Williams etc.

Like the proverbial goldfish that has no hiding place, they are always in the face of the camera and thereby always up for public scrutiny regardless of wherever they find themselves. Advertisers cash in on this fact to promote their products and services. In other words, they act as spokespersons as regards advertising to promote goods and services, (Kambitsis et al., 2002, Tom et al., 1992 in Schlecht, 2003). For instance, at red carpets events, reporters and fans are always eager to know the name of the designers of the clothes and footwears they are putting on. No matter how ridiculous the outfit looks, as long as it is good enough for a celebrity, then it is automatically vetoed (well, in exception of the fashion police and fashion court that criticizes the celebrity's looks and outrageous outfits).

Use of celebrity is understandable in as much consumers readily identify with these stars, often regarding them as heroes and heroines for their accomplishments, personalities, and physical appeal. (Shimp, 2000: p. 332). The fondness of using celebrities is because of their famous attributes-including courage, talent, athleticism, grace, power and sex appeal. These often represent the attractions desired for the brand they endorse. By association, consumers often prefer those brands owing to the conception that it helps in shaping that celebrity; helps in defining his/her style.

However, source credibility in advertising is also influenced by source attractiveness. The more attractive a celebrity looks, the more likely consumers are to buy whatever he/she is selling. In other words, the level of appeal to the eyes influences the impact on buying behaviors, brand preferences and attitudinal changes. In the words of Shimp (2000),

attractiveness exceeds physical attractiveness to include intellectual skills, personality properties, lifestyle characteristics, athletic prowess and so on.

Empirical evidence suggests the notion that physically attractive endorsers or models tend to produce more favourable evaluation of advertisements and advertised products than do less attractive endorsers.

Though, I must add that the effectiveness is heightened when the endorser's image is compatible with the nature of the endorsed product.

Another factor that positively or negatively affects source credibility in relation to advertising and celebrity endorsements is the "match up" or a fitting relationship between the spokesperson and the product. What do I mean? Celebrity status will have little or no role to play if a vegetarian celebrity is used to advertise beef products; non smokers to advertise cigarettes; or to use a dark complexioned celebrity to advertise a toning or lightening cream. Contextualizing this, Hill \& Busler 1998 in Schlecht (2003) explains that

the match up hypothesis specifically suggest that the effectiveness depends on the existence of a "fit" between the celebrity spokesperson and endorsed brand.

Shrimp (2000) went a step further to state that it is not enough for there to exist a relationship between the model and the product. To aid believability, there ought to be a meaningful relationship or match up, between the celebrity, the audience, and the product. In other words, there ought to be a significant 
connection between the model and the product or service as the case may be. This time around, the "who" and "what" is not enough to cover the fitting.

Another factor that affects credibility is expertise and trustworthiness. Here, the fact that you are a celebrated person is not enough to influence consumer's attitudes. According to Shimp (2000),

...two important properties of endorsers' credibility are expertise and trustworthiness. Expertise refers to the knowledge, experience, or skills possessed by an endorser as they relate to the communication topic.

An example is a mother (celebrity or not) endorsing mother care products. There is the tendency to see the source as credible because as a mother, she knows what a mother generally wants.

Trustworthiness according to Shimp (2000) refers to the honesty and believability of a source. An endorser's trustworthiness depends primarily on the audience's perception of his or her endorsement motivations. If the audience believes that an endorser is motivated purely by self interest, he or she will be less persuasive than an audience perceives as having nothing to gain by endorsing the product or as being completely objective.

It all boils down to presenting oneself before, during, and after the campaign as honest, believable and dependable.

\section{Relationship between Source Credibility and Politics}

There appears to be some acceptance of the belief that the characteristics of a communicator influence an audience's reception of a message. This belief affects not only the use of testimonials for commercial advertising but also the choice of endorsers for political candidates and social causes. Researchers have found that sources having more of the credibility dimensions induce greater attitude change immediately than do sources having less of those dimensions, Dhokolia (1987).

In politics and public administration, credibility and charisma seems to have become a highly sought-after quality and virtue. What role does source credibility play with regards to politics? For a start, what is it about Obama that made Americans to vote for a black man? For some, it is as a result of his confident and credible appearance; for a few, it is about his organized and coordinated campaign plan; while for those who understood the rules of the game, it is about "additional performative qualities that includes things like rhetoric, timing, appropriateness, charisma, eloquence, responsiveness and vision” (www.primo-europ. eu) .

To answer how he was able to achieve that feat; I quote the words of Aristotle in Teven (2008) which reads thus:

More than 2500 years ago, Aristotle espoused that the source of a message contributes to the persuasiveness of that message. Credibility is the image of the source in the minds of receivers. This is what Aristotle calls the source's ethos and explains that it is the source's most potent means of persuasion.

According to Aristotle, ethos plays the most important role in influencing the audiences' thought and beliefs. Such an ethos implies the communicators' knowledge and understanding of the message coupled with moral authority and expressed goodwill of the message sender. It is the known contributing factor for the credibility and trust vested in the communicator.

Also writing on the role of source credibility in political communication context, Richmond \& McCroskey 1975 in Teven (2008) states that "credibility is a critical factor in the selection of opinion leaders". The source credibility boots candidate's image which is a major determinant in voters' behaviours and candidates' selection. In other words, the success or failure of any political campaign or endeavor depends on how credible the voters perceive the candidate to be.

While expertise and trustworthiness affects credibility in advertising, source credibility in politics consists of competence, trustworthiness, and goodwill. Here, competence shoots out from expertise because one cannot claim to be competent in an area where you are a novice. The electorates need someone who looks competent enough to steer the train of government through murky waters.

Despite the components of goodwill, competence and trustworthiness, I assert that the keyword is all about charisma and presentation. How were you able to convince the electorates that you empathize with them? How are you able to sway the voters to your side against your contenders? These questions have to be addressed if the words of McCroskey are anything to go by. According to McCroskey 1971 in Teven (2008: p. 386)

a political contest is in essence a contest in credibility and the audience will vote for the person at election time whom they perceive to be the most credible.

An example of source credibility at play vis-à-vis political success can be found in the research by Teven (2008) which examined the perceived credibility of the 2008 American presidential election. The primary purpose of the research was to examine and explore the relationships between voter perceptions of candidate's credibility, believability, likeability, and deceptiveness. The findings saw Barak Obama, the current president of America, scoring highest in believability, likeability, competence, trustworthiness and goodwill. Out of the 5 candidates used as a case study, he scored the lowest in deceptiveness. This finding demonstrates that candidate's believability and likeability have significant, positive relationship with voter's perceptions of candidate's credibility, Teven (2008).

How was that possible? How did Obama do it? How was he able to sway the people? He was able to communicate positive traits to the electorate; a kind of transfer of passions from his heart to the people. With his passionate approach, he was able to transcend the barriers of racism and rose above the competition.

\section{Source Credibility and Religion}

When it comes to opinion leadership, religious leaders are often prominent on a range of social, economic and religious issues. Many people often consciously or unconsciously look up to the religious leaders or clergy people on difficult and pressing matters. If that is the case, then they have the ability to sway the opinion of their members or followers. How are they able to maintain that "opinion leadership statuses"? Why do people of all religion feel more comfortable asking and taking advice from religious leaders? It has only one answer and that issource credibility.

Given that credibility can be seen as a mixture of trustworthiness, expertise and attractiveness (Dholakia \& Sternthal, 1977 in Levine \& Stephenson, 2007), it is reasonable to anticipate that expertise should increase the credibility of a messenger. That is, does a leader's credibility depend on him/her 
speaking from a position that is commensurate with their acknowledged expertise? From the position that leaders occupy in the society, they might not necessarily be experts for their followers to agree with them. This is because, it is believed that they are channels through which God speaks to human; if they represent God, then they are filled with divine knowledge and expertise needed to deal with an issue.

The ability to be convincing to the extent of having the desired effect lies in how credible most of the followers see him to be. However, it is anticipated that the views of a religious leader, when rooted in scriptural or moral imperatives, will resonate more with the public than if he/she based his/her argument in economic logic, Levine \& Stephenson (2007). While a religious leader may be a credible authority, he/she is not necessarily an appropriate figure to argue an issue from a material viewpoint. Similarly, a politician using an ethical argument would seem, in the abstract, less effective than a religious leader doing the same thing.

While that might be true in the foreign scene, it is alien in Nigeria because, Nigerians are highly religious people and have the tendency of hanging to the words of their spiritual directors. Here, religious leaders speak authoritatively on politics and political candidates, the economy to an extent and morality. Primarily, the aim is to let the people be in the know and to commit their unflinching faith to God who will help them rise above any situation they may find themselves. From the point view of goodwill, they are seen as credible since they have the interest of the public at heart. They are there, for and only for their followers; I believe that is enough to have ardent followers.

\section{Summary and Analysis}

In summary, an analysis of the source credibility theory reveals the theory to be scientific in nature. The theory also has high level of internal consistencies. The three main models as was gathered in the course of literature review namely; the factor model; the functional models; and the constructivist model allow the theory to have much more organizing power. This model helps it to be relevant in studying communication effects at all times.

While the factor model helps to determine to what extent the receiver judges the source as credible, the functional model views credibility as the degree to which a source satisfies a receivers needs and the constructivist model analyses what the receiver does with the sources proposal. This is where active construction kicks in.

Well, the summary of this paper is that being perceived as credible should be strived for in the face of challenges and competitions. One has to package oneself so that what you present to others works to your advantage. I believe it is what we all need at one point or another to be seen as relevant.

\section{REFERENCES}

Baudhin, S., \& Davis, M. (1972). Scales for the Measurement of Ethos:
Another Attempt. Speech Monographs, 39, 296-301. doi:10.1080/03637757209375769

Cornan, S., Hess, A., \& Justus, Z. (2006). Credibility in the Global war in Terrorism: Strategic Principles and Research Agenda. Consortium for Strategic Communication, Phoenix Metropolitan Area: Arizona State University.

Daneshvary, R., \& Schwer, K. (2000). The Association Endorsement and Consumers' intention to purchase. Journal of Consumer Marketing, 17, 203-213. doi:10.1108/07363760010328987

Dholakia, R. R. (1987). Source Credibility Effects: A Test of Behavior Persistence. Advances in Consumer Research, 14, 426-430.

Eisend, M. (2006). Source Credibility: Dimensions in Marketing Communication-A Generalized Solution. Journal of Empirical Generalizations in Marketing Science, 10, 1-33.

Gilbert, D., Fike, S., \& Lindzey, G. (1998). The Handbook of Psychology. Oxford: Oxford University Press.

Gotlieb, J., \& Sarrel, D. (1991). Comparative Advertising Effectiveness: The Role of involvement and Source Credibility. Journal of Advertising, 20, 38-45.

Hovland, C., \& Weiss, W. (1951). The Influence of Source Credibility on Communication Effectiveness. Public Opinion Quarterly, 15, 635- 650. doi:10.1086/266350

Hovland, C., Janis, I., \& Kelley, H. (1953). Communication and Persuasion. New Haven, GT: Yale University Press.

Hunter, J. (2001). The Desperate need for Replications. Journal of Consumer Research, 28, 149-158. doi:10.1086/321953

Kalbgfleish, P. ( 2003). Communication Yearbook, 297-299.

Levine, R., \& Stephenson, L. (2007). Message or Messenger? The Limits of moral Leadership. URL (last checked 22 January 2012). www.bepress.com/renan

Marcus, G. (1995). With malice towards some: How people make Civil Liberty Judgment. Cambridge: Cambridge University Press.

McCroskey, J. (1958). Scales for the Measurement of Ethos. Speech Monographs, 33, 67-72.

O'Keefe, D. J. (2002). Persuasion: Theory and research (2nd ed.). Beverly Hills: Sage Publications.

Remage, J., \& Bean, C. (1998). Writing arguments (1st ed.). Nickham Heights, MA: Ally \& Bacon. 81-82.

Schlecht, C. (2003). Celebrities Impact on Branding. Columbia: Columbia Business School.

Shimp, T. A. (2000). Advertising Promotion. Supplemental aspects of Integrated Marketing Communications (5th ed). San Diego, CA: Harcourt College Publishers.

Siu, W. L.-W. (2007). Prime, Frame, and Source factors: Semantic valence in message judgment. Journal of Applied Social Psychology, 37, 2364-2375. doi:10.1111/j.1559-1816.2007.00262.x

Solomon, M. (2002). Consumer behavior: Buying, Having, and Being (5th ed.). Englewood Cliffs, NJ: Prentice Hall.

Tellis, G. (2003). Effective Advertising: Understanding When, How and Why Advertising Works. Beverly Hills: Sage Publications.

Teven, J. (2008). An Examination of Perceived Credibility of the 2008 Presidential Candidates: Relationships with Believability, Likeability, and Deceptiveness. Human Communications, 11, 383-400.

The Quest for Credibility in Politics and Public Administration (2010). URL (last checked 22 January 2012). www.primo-europe.eu

Wayne, S. (2002). The road to the White House. New York: St Martin's Press.

www.wikipedia.org

Zaller, J. (1992). The Nature and Origin of Mass Opinion. Cambridge: Cambridge University Press. 